\title{
Multiple strategies to improve the yield of chitinase a from Bacillus licheniformis in Pichia pastoris to obtain plant growth enhancer and GICNAC
}

\author{
Wen Song, Nuo Zhang, Mo Yang, Yuling Zhou, Nisha He* and Guimin Zhang *
}

\begin{abstract}
Chitinase and chitin-oligosaccaride can be used in multiple field, so it is important to develop a high-yield chitinase producing strain. Here, a recombinant Pichia pastoris with 4 copies of ChiA gene from Bacillus licheniformis and coexpression of molecular chaperon $\mathrm{HACl}$ was constructed. The amount of recombinant ChiA in the supernatant of high-cell-density fermentation reaches a maximum of $12.7 \mathrm{mg} / \mathrm{mL}$, which is 24-fold higher than that reported in the previous study. The recombinant ChiA can hydrolyze $30 \%$ collodidal chitin with $74 \%$ conversion ratio, and GIcNAc is the most abundant hydrolysis product, followed by N, N'-diacetylchitobiose. Combined with BsNagZ, the hydrolysate of ChiA can be further transformed into GlcNAc with $88 \%$ conversion ratio. Additionally, the hydrolysate of ChiA can obviously accelerate the germination growth of rice and wheat, increasing the seedling height and root length by at least 1.6 folds within 10 days.
\end{abstract}

Keywords: Chitinase, Pichia pastoris, Colloidal chitin, GlcNAc, Plant growth

\section{Introduction}

Chitin is the second abundant bioresource that is widely distributed in wastes from shellfish, krill processing, fungal fermentations and green alga. It is constituted of $\beta(1 \rightarrow 4)$-linked $N$-acetyl-D-glucosamine (GlcNAc) units [1]. Chitin can be degraded by chitinases, which takes place in 2 steps, the initial cleavage of the chitin polymer by chitinases into chitin-oligosaccharide and further cleavage to GlcNAc by $\beta-N$-acetylglucosaminidase [2]. Chitin-oligosaccharide can promote plant growth and induce crops to produce disease resistance factors, effectively resist the infection of plant pathogens $[3,4]$. GlcNAc can prevent bone and joint diseases, promote

*Correspondence: henisha@hubu.edu.cn; nshe1992@163.com; zhangguimin@hubu.edu.cn; zhangguimin6@hotmail.com State Key Laboratory of Biocatalysis and Enzyme Engineering, School of Life Sciences, Hubei University, Wuhan 430062, China wound healing, and be as antibacterial and anti-inflammatory agent $[5,6]$. Therefore, it can be widely used in the industry of medicine, health care, food and cosmetics. At present, the chitin-oligosaccharide and GlcNAc are mainly prepared from chitin through chemical method, which cause severe environmental issues. Thus, using chitinases to hydrolyze chitin, with the mild reaction conditions and less pollution, has become a popular research direction. So, it is important to develop a highyield chitinase producing strain to lower the cost of chitin hydrolysis into GlcNAc and chitin-oligosaccharides.

Bacillus licheniformis is a GRAS organism, has been used extensively in industry for the production of various enzymes and metabolites [7, 8]. Songsiriritthigul et al. firstly expressed the ChiA from B. licheniformis in Escherichia coli and characterized the recombinant enzyme. They found that ChiA is thermo and pH-stable, hydrolyzing colloidal chitin into GlcNAc and $N$,

(c) The Author(s) 2020. This article is licensed under a Creative Commons Attribution 4.0 International License, which permits use, sharing, adaptation, distribution and reproduction in any medium or format, as long as you give appropriate credit to the original author(s) and the source, provide a link to the Creative Commons licence, and indicate if changes were made. The images or other third party material in this article are included in the article's Creative Commons licence, unless indicated otherwise in a credit line to the material. If material is not included in the article's Creative Commons licence and your intended use is not permitted by statutory regulation or exceeds the permitted use, you will need to obtain permission directly from the copyright holder. To view a copy of this licence, visit http://creativeco mmons.org/licenses/by/4.0/. The Creative Commons Public Domain Dedication waiver (http://creativecommons.org/publicdomain/ zero/1.0/) applies to the data made available in this article, unless otherwise stated in a credit line to the data. 
$N^{\prime}$-diacetylchitobiose [9]. However, expression of ChiA in E. coli is not suitable for industrial applications for its cell disruption, high cost of inducer and protein purification, etc. Then, Menghiu et al. expressed ChiA extracellularly in $P$. pastoris. The recombinant ChiA was glycosylated and the yield in the supernatant reached $0.506 \mathrm{mg} / \mathrm{mL}$ in the $1 \mathrm{~L}$ flask, which is fivefold than the one in E. coli [10]. However, the yield is still far from the requirement of industrial application, multiple strategies are still needed to increase the expression of recombinant ChiA in yeast.

P. pastoris has been widely used to produce heterologous protein with its advantages of secretory expression with less background extracellular protein [11]. Recently, multiple strategies have been developed for efficient expression of heterologous protein in P. pastoris, such as optimizing the expression vector, increasing the copy number of target gene, co-expressing molecular chaperone, optimizing the fermentation conditions, and so on $[12,13]$. In our previous job, the pHBM905M vector used in this study was constructed based on the pHBM905A plasmid [14] with four major modifications, including the replacement of original AOX1 promoter by $\mathrm{d} 1+2 \times 201 \mathrm{AOX} 1$ promoter, the replacement of original MF $\alpha$ signal peptide by MF4I-SS signal peptide, and the removal of kanamycin resistance gene by the insertion of heterologous gene during the plasmid construction. In addition, pHBM905M can use the Biobrick method to generate a multi-copy expression cassette in vitro $[15,16]$. Moreover, there is no exogenous resistance genes in the recombinant $P$. pastoris, which decreased the spread of antibiotics resistance genes to the environment. Molecular chaperones were also used to increase the expression of heterologous proteins in P. pastoris. HAC1 can trigger the unfolded protein response (UPR) and increase the secretion of recombinant proteins which were demonstrated in many studies. For example, co-expression of HAC1 increased the expression of $\Delta 9$-Tetrahydrocannabinolic acid synthase 4.1-fold [17]. TRM1 is a transcription factor which is important for the transcriptional activation of genes of methanol utilization pathway in $P$. pastoris [18]. As P. pastoris is a methylotrophic yeast, which utilize methanol as the only energy and carbon source. The heterologous gene expression is also driven by methanol-inducible promoters, thus, we speculated that TRM1 can promote the utilization efficiency of methanol, resulting in higher expression level of heterologous protein. ERV29, SEC16 and COG5 are involved in the secretory and trafficking pathway, which have been identified to improve the secretion of recombinant proteins in S. cerevisiae $[19,20]$. Thus, we proposed that co-expression of those chaperones with the target gene seems to be a general strategy for enhancing the expression of recombinant proteins in P. pastoris. In addition, $P$. pastoris has strong aerobic growth preferences and can perform high-cell-density fermentation, which is conducive to large-scale industrial production.

In our study, different strategies were used to optimize the expression level of ChiA, containing chromosome insertion of multiple ChiA expression cassettes on the basis of the vector pHBM905M, co-expression with molecular chaperones (HAC1, TRM1, EVR29, SEC16, COG5) and high-cell-density fermentation. The recombinant ChiA can act on $30 \%(w / v)$ colloidal chitin with high conversion ratio, and the hydrolysis product can be further transformed into GlcNAc by combining with reported $\beta-N$-acetylglucosaminidase. Moreover, the plant germination-promoting activity of hydrolysate were also investigated.

\section{Materials and methods}

\section{Plasmids, strains, chemicals and medium}

For gene cloning, E. coli XL-gold was purchased from Invitrogen. The P. pastoris GS115 strain was used for the heterologous expression. The plasmid pHBM905M was used as expression vector to carry ChiA gene, which originally constructed in our group [16]. The plasmid pGAPZB from Invitrogen was used to express HAC1, ERV29, SEC16, COG5 and TRM1 constitutively. BMGY (buffered glycerol-complex medium), BMMY (buffered methanol-complex medium), MD (minimal dextrose) media were prepared according to the instruction of Pichia Expression Kit (Invitrogen, USA). $\mathrm{PTM}_{1}$ (Pichia trace metals) solution was prepared as $6.0 \mathrm{~g} / \mathrm{L} \mathrm{CuSO}_{4} \cdot 5 \mathrm{H}_{2} \mathrm{O}, 0.08 \mathrm{~g} / \mathrm{L} \mathrm{NaI}, 3.0 \mathrm{~g} / \mathrm{L}$ $\mathrm{MnSO}_{4} \cdot \mathrm{H}_{2} \mathrm{O}, 0.2 \mathrm{~g} / \mathrm{L} \mathrm{Na}_{2} \mathrm{MoO}_{4} \cdot 2 \mathrm{H}_{2} \mathrm{O}, 0.02 \mathrm{~g} / \mathrm{L} \mathrm{H}_{3} \mathrm{BO}_{3}$, $0.5 \mathrm{~g} / \mathrm{L} \mathrm{CoCl}, 20.0 \mathrm{~g} / \mathrm{L} \mathrm{ZnCl} 2,65.0 \mathrm{~g} / \mathrm{L} \mathrm{FeSO}_{4} \cdot 7 \mathrm{H}_{2} \mathrm{O}$, $0.2 \mathrm{~g} / \mathrm{L}$ biotin, $5 \mathrm{~mL} / \mathrm{L} \mathrm{H}_{2} \mathrm{SO}_{4}$. Basal salts medium was prepared as $20 \mathrm{~g} / \mathrm{L} \mathrm{NH}_{4} \mathrm{H}_{2} \mathrm{PO}_{4}, 0.9 \mathrm{~g} / \mathrm{L} \mathrm{CaSO}_{4}, 12 \mathrm{~g} / \mathrm{L}$ $\mathrm{K}_{2} \mathrm{SO}_{4}, 10 \mathrm{~g} / \mathrm{L} \mathrm{MgSO} \cdot 7 \mathrm{H}_{2} \mathrm{O}, 4 \mathrm{~g} / \mathrm{L} \mathrm{KH}_{2} \mathrm{PO}_{4}, 0.6 \mathrm{~g} / \mathrm{L}$ $\mathrm{KOH}, 40 \mathrm{~mL} / \mathrm{L}$ Glycerol. The B. licheniformis WX-02 was provided by Prof. Shouwen Chen from Hubei University. Based on the sequence in GenBank (Accession Number CP012110.1, 311870-313657 bp), the DNA primers were synthesized by Sangon Biotech Co., Ltd. (Shanghai, China). A Bradford assay kit for protein quantification in the fermentation supernatant was purchased from Beyotime Biotechnology (Shanghai, China). GlcNAc and $N, N^{\prime}$-diacetylchitobiose were purchased from BZ Oligo Biotech Co., LTD (Qingdao, China) as controls. Restriction enzymes, DNA polymerase, DNA Ligation Kit, and other related reagents were bought from Takara (Dalian, China). 


\section{Construction of the multi-copy expression cassette plasmids}

The primers used in this study are listed in Table 1 . The ChiA gene from $B$. licheniformis was amplified by PCR with primers ChiA-F and ChiA-R, then cloned into the expression vector $\mathrm{pHBM} 905 \mathrm{M}$ digested by $\mathrm{CpoI}$ and NotI (Additional file 1: Fig. S1). The recombinant plasmid included single copy of ChiA was confirmed by sequencing and named as pHBM905M-ChiA-1C (Additional file 1: Fig.S2A). Based on pHBM905M-ChiA-1C, other multiple copies of $C h i A$ gene were constructed through the biobrick method [21]. The whole expression cassette was cleaved from the plasmid pHBM905M-ChiA-1copy using $X b a \mathrm{I} / \mathrm{BamHI}$, then cloned into the pHBM905MChiA-1copy with SpeI/BamHI digestion to generate pHBM905M-ChiA-2copy plasmid, which contained 2 copies of expression cassette. The $\mathrm{XbaI}$ and SpeI are isocaudamer, so the ligation would destroy the original SpeI site in the plasmid pHBM905M-ChiA-2copy (Additional file 1: Fig. S2A). The plasmids containing 3, 4 and 6 copies of the ChiA expression cassettes were constructed by repeating this procedure, then confirmed by plasmid size and SalI digestion (Additional file 1: Fig.S2B), and then transformed into P. pastoris GS115.

\section{Expression of ChiA in P. pastoris through shake flask fermentation}

The five recombinant plasmids (pHBM905M-ChiA1copy, pHBM905M-ChiA-2copy, pHBM905M-ChiA3copy, pHBM905M-ChiA-4copy and pHBM905M-ChiA6copy) were linearized by $S a l$ I and electroporated into $P$. pastoris GS115. All transformants were selected on MD plates containing $0.4 \mathrm{mg} / \mathrm{L}$ biotin without histidine, and then identified by PCR to amplify the ChiA. The recombinant $P$. pastoris strains, A1C, A2C, A3C, A4C and A6C,

Table 1 The primers used in the study

\begin{tabular}{ll}
\hline Primers name & Sequence \\
\hline ChiA-F & GTCAGATTCCGGAAAAAACTATAAAATCATCGGC \\
ChiA-R & GGCCATTATTCGCAGCCTCCGATCAGCC \\
HAC1-F & GATTCCAATCATTTTTTTTTTTTGTCTGTGTATTCTTCTTA \\
HAC1-R & GAATTCATGTCTTATCGCCCTCAGTTTCAACA \\
ERV29-F & GTCGAGTCAATAGATCTTTTTCTTTTCATCAAAACTCAA \\
ERV29-R & GATTCATGGTTACAATTGGAAACGCACAT \\
SEC16-F & GAATTCATGTCTTTGGGATCGACTTCGCCAGC \\
SEC16-R & CTCGAGTTAGCCATTCAATACCCTAATAGCATTATAATCATC \\
COG5-F & GAATTCCTATCGCACCTCACTCATAGAAAATC \\
COG5-R & TRMAGGGGGGGGGCATTCTAGTATGTACAAATAG \\
TRM1-R &
\end{tabular}

were cultured respectively in $50 \mathrm{~mL}$ BMGY medium until the $\mathrm{OD}_{600}$ reached 20-25. Then the yeast cells were transferred into $25 \mathrm{~mL}$ BMMY medium, and incubated at $28{ }^{\circ} \mathrm{C}$. We added $125 \mu \mathrm{L}$ methanol to induce target protein expression every $12 \mathrm{~h}$, with a total induction time of 7 days. Every $24 \mathrm{~h}$, the cell culture were collected for measurement of enzyme activity and analyzed on a $12 \%$ SDS-PAGE.

\section{Co-expression of $\mathrm{ChiA}$ with molecular chaperones}

The HAC1, ERV29, SEC16, COG5, and TRM1 genes from $P$. pastoris GS115 were amplified by PCR (Primers in Table 1), and cloned into the pGAPZB vector respectively (Additional file 1: Fig. S3). Then, these constitutive expression vectors were linearized with AvrII and transformed individually into $P$. pastoris $\mathrm{A} 4 \mathrm{C}$, and the transformants were selected on YPD plates with $100 \mu \mathrm{g} / \mathrm{mL}$ zeocin. The right recombinant strains were verified using colony PCR, respectively. The P. pastoris A4C, co-expression with HAC1, ERV29, SEC16, COG5, and TRM1were cultured respectively in $50 \mathrm{~mL}$ BMGY medium until the $\mathrm{OD}_{600}$ reached 20-25. Then the yeast cells were transferred into $25 \mathrm{~mL}$ BMMY medium, and incubated at $28{ }^{\circ} \mathrm{C}$. We added $125 \mu \mathrm{L}$ methanol to induce target protein expression every $12 \mathrm{~h}$, with a total induction time of 7 days. Every $24 \mathrm{~h}$, the cell culture were collected for measurement of enzyme activity and analyzed on a $12 \%$ SDS-PAGE.

\section{Analysis of chitinase activity on colloidal chitin}

DNS method was used to measure the activity of ChiA towards colloidal chitin [22]. The colloidal chitin was prepared as previously described [23]. The fermentation supernatant was collected by centrifuging at $10,000 \mathrm{~g}$ for $5 \mathrm{~min}$ at $4{ }^{\circ} \mathrm{C}$. The mixture with $500 \mu \mathrm{L} 2 \%(\mathrm{w} / \mathrm{v})$ colloidal chitin and $50 \mu \mathrm{L}$ fermentation supernatant was incubated at $50{ }^{\circ} \mathrm{C}$ for $10 \mathrm{~min}$, then $500 \mu \mathrm{L}$ DNS was added and the mixture was incubated at $100{ }^{\circ} \mathrm{C}$ for $15 \mathrm{~min}$. The mixture was centrifuged at $10,000 \mathrm{~g}$ for $1 \mathrm{~min}$ at room temperature to precipitate the non-hydrolyzed chitin, and the supernatant was transferred to a cuvette and the absorbance at $540 \mathrm{~nm}$ was measured to quantify the concentration of reducing sugars. One unit of ChiA activity is defined as the quantity of enzyme needed to release $1 \mu \mathrm{M}$ GlcNAc per minute.

\section{High-cell-density fermentation of A4C co-expressing with $\mathrm{HAC} 1$}

In order to improve the ChiA expression level continually, we used $5 \mathrm{~L}$ high-cell-density fermentation according to the Pichia fermentation process guidelines (Invitrogen), which included three stages [24]. Firstly, a fresh colony was inoculated into $200 \mathrm{~mL}$ YPD medium, incubated 
at $28{ }^{\circ} \mathrm{C}$, and $200 \mathrm{rpm}$ for $48 \mathrm{~h}$, then transferred into $5 \mathrm{~L}$ fermentor with $2 \mathrm{~L}$ of the basal salt medium with $8 \mathrm{~mL} / \mathrm{L} \mathrm{PTM}_{1}$ solution to keep the initial $\mathrm{OD}_{600}$ about 0.5 . During the cell growth stage, the temperature was set at $28^{\circ} \mathrm{C}$, and the $\mathrm{pH}$ was maintained at 6.0 by adding ammonia hydroxide. The cells were allowed to grow until the glycerol was exhausted, as indicated by an increase of DO (Dissolved oxygen) level. The glycerol was exhausted after $29 \mathrm{~h}$, DO increased to $60 \%$ rapidly. Then the second stage was initiated by feeding $50 \%(\mathrm{w} / \mathrm{v})$ glycerol containing $12 \mathrm{~mL} / \mathrm{L} \mathrm{PTM}_{1}$ solution, and the feeding rate was varied to maintain the DO level at $20-30 \%$. When the $\mathrm{OD}_{600}$ of cells reached 300 , the glycerol feeding was stopped, DO rose again. About 30 min later, the third stage of the fermentation began with the feeding of pure methanol containing $12 \mathrm{~mL} / \mathrm{L} \mathrm{PTM}_{1}$ solution into the fermenter to induce the expression of the target gene, and the feeding rate was varied to maintain the DO level at $20-30 \%$. The fermentation temperature was adjusted to $22{ }^{\circ} \mathrm{C}$ [16]. Samples were collected every $12 \mathrm{~h}$ from cell culture to determine the $\mathrm{OD}_{600}$ and enzyme activity.

\section{Recombinant ChiA hydrolyzes colloidal chitin at different concentrations}

The reaction mixtures, including $200 \mu \mathrm{L}$ ChiA (18 U/ $\mathrm{mL}$ ) mixed with $500 \mu \mathrm{L} 10 \%, 15 \%, 25 \%, 30 \%, 35 \%$ and $40 \%$ colloidal chitin respectively were incubated at $50{ }^{\circ} \mathrm{C}$ for $12 \mathrm{~h}$. The reaction products were determined by high performance liquid chromatography (HPLC), using Nexera UHPLC/HPLC System with a Zorbax Carbohydrate Analysis Column $(4.6 \times 250 \mathrm{~mm}, 5 \mu \mathrm{m})$ (Agilent, America). The mobile phase consisted of acetonitrile and water (70:30, v/v). The flow rate was $0.5 \mathrm{~mL} / \mathrm{min}$. Products were detected at $190 \mathrm{~nm}$. The injection volume was $20 \mu \mathrm{L}$. The DNS method was used to determine the reducing sugar concentration, and the conversion ratio was calculated by comparing the quantity of actual reducing sugars over the actual colloidal chitin dry weight. The optimum colloidal chitin concentration is determined by comparison of conversion ratio and the amount of reaction products by HPLC.

\section{ChiA hydrolyzing colloidal chitin combined with BsNagZ to obtain GIcNAc}

The reaction mixture including $300 \mu \mathrm{L} 1 \mathrm{mM} N, N^{\prime}$ diacetylchitobiose and $50 \mu \mathrm{L}$ ChiA $(18 \mathrm{U} / \mathrm{mL})$ was incubated at $50{ }^{\circ} \mathrm{C}$ for $20 \mathrm{~min}$. The reaction products were also analyzed by HPLC. The hydrolysis ratio of $N, N^{\prime}$-diacetylchitobiose was calculated according to the standard curve drafted by the peak areas of standard and each experiment was repeated three times to minimize the experimental deviation. The hydrolysis rate of $N, N^{\prime}$-diacetylchitobiose (\%)= released GlcNAc $(\mathrm{mg}) \times 100 \% /$ Original $N, N^{\prime}$-diacetylchitobiose $(\mathrm{mg})$.

BsNagZ is $\beta-N$-acetylglucosaminidase from $B$. subtilis, which has been identified to cut the colloidal chitin from the terminal to obtain GlcNAc with low efficiency, combining commercial chitinase can improve the yield of GlcNAc efficiently in our previous work [25]. Here, a mixture of $600 \mu \mathrm{L}$ of $30 \%(\mathrm{w} / \mathrm{v})$ colloidal chitin and $200 \mu \mathrm{L}$ ChiA $(18 \mathrm{U} / \mathrm{mL})$ was kept at $50{ }^{\circ} \mathrm{C}$ for $12 \mathrm{~h}$, and $200 \mu \mathrm{L}$ BsNagZ (5 U/mL) was added and the mixture further incubated at $60{ }^{\circ} \mathrm{C}$ for another 20 min to obtain GlcNAc. The reaction products were then analyzed by HPLC, and GlcNAc was quantified using the standard curve. The conversion ratio $(\%)=$ released GlcNAc $(\mathrm{mg}) \times 100 \% /$ the colloidal chitin dry weight $(\mathrm{mg})$.

\section{Influence of chitin-oligosaccharides on seed germination and seedling growth of rice and wheat}

In order to explore the optimal concentration of chitinoligosaccharides to promote the germination of rice and wheat. Fifty grains of rice and wheat seeds of uniform size were selected and placed in a Petri dish, respectively. The rice seeds were soaked with $50 \mu \mathrm{g} / \mathrm{mL}, 150 \mu \mathrm{g} / \mathrm{mL}$, $300 \mu \mathrm{g} / \mathrm{mL}$ and $500 \mu \mathrm{g} / \mathrm{mL}$ ChiA 12 h-hydrolyzed products on colloidal chitin respectively, likewise, $1 \mu \mathrm{g} / \mathrm{mL}$, $10 \mu \mathrm{g} / \mathrm{mL}, 25 \mu \mathrm{g} / \mathrm{mL}$ and $100 \mu \mathrm{g} / \mathrm{mL}$ hydrolysate for the wheat seeds, and the distilled water as the control. The samples were hydrated every day with a sprayer, and germinated at room temperature for 7-10 days to observe the germination and growth of rice and wheat seeds.

Then, another fifty grains of rice and wheat seeds of uniform size were selected and placed in a Petri dish. Since colloidal chitin is dissolved in $0.1 \mathrm{M} \mathrm{pH} 6.0$ phosphate buffer, we also use phosphate buffer as a control. The seeds were then soaked at room temperature with water, phosphate buffer ( $\mathrm{pH}$ 6.0), ChiA 12 h-hydrolyzed products on colloidal chitin and ChiA/BsNagZ hydrolyzed products on colloidal chitin $(300 \mu \mathrm{g} / \mathrm{mL}$ for rice seeds, $10 \mu \mathrm{g} / \mathrm{mL}$ for wheat seeds), respectively. The samples were hydrated daily with a sprayer, and germinated at room temperature for 7-10 days to measure the root and bud length. The average value and variance of each group were calculated and Student's $t$ test was used to analyze differences between experiment group and control group.

\section{Results}

\section{Induced expression of ChiA in P. pastoris}

The molecular weight of ChiA is $76.20 \mathrm{kDa}$ predicted by the ExPASy Bioinformatics Resource program, and the ChiA has 7 potential N-glycosylation sites. The recombinant ChiA was previously identified as an glycosylated enzyme in $P$. pastoris through deglycosylation treatment 
[10]. Here, the recombinant ChiA migrated as an about $100 \mathrm{kDa}$ band through SDS-PAGE analysis (Fig. 1a), same as the previous report [10]. As the copy of gene increases, the secretory expression of ChiA also improved from the strain $\mathrm{A} 1 \mathrm{C}$ to $\mathrm{A} 4 \mathrm{C}$, while the strain $\mathrm{A} 6 \mathrm{C}$ secreted the less ChiA (Fig. 1a). Activity analysis showed that P. pastoris A4C gave the highest enzyme activity and expression level on the 6th day of induction, reaching $16.74 \mathrm{U} / \mathrm{mL}$ $(1.13 \mathrm{mg} / \mathrm{mL})$, higher than the strain with $1,2,3$ and 6 copies of ChiA on the 6th day with $8.84 \mathrm{U} / \mathrm{mL}(0.53 \mathrm{mg} /$ $\mathrm{mL}), 13.13 \mathrm{U} / \mathrm{mL}(0.84 \mathrm{mg} / \mathrm{mL}), 14.20 \mathrm{U} / \mathrm{mL}(1.05 \mathrm{mg} /$ $\mathrm{mL})$ and $15.41 \mathrm{U} / \mathrm{mL}(1.07 \mathrm{mg} / \mathrm{mL})$ respectively (Fig. 1b).

\section{Co-expression of molecular chaperones to improve the yield of ChiA}

The AvrII-linearized vectors pGAPZB-HAC1/ERV29/ SEC16/COG5/TRM1 was transformed into P. pastoris A4C, respectively. Co-expression of HAC1 and ERV29 separately increased the ChiA yield in the fermentation supernatant of flask from $16.74 \mathrm{U} / \mathrm{mL}(1.13 \mathrm{mg} / \mathrm{mL})$ to $20.69 \mathrm{U} / \mathrm{mL}(1.40 \mathrm{mg} / \mathrm{mL})$ and $19.00 \mathrm{U} / \mathrm{mL}(1.26 \mathrm{mg} /$ $\mathrm{mL}$ ), respectively (Fig. 2a). However, co-expression of SEC16, COG5 or TRM1 didn't give obvious promotion for ChiA expression (Fig. 2). We also tried to express $H A C 1$ and ERV29 simultaneously in A4C strain, yet the activity did not further increase compared with coexpression of single chaperone. Thus, co-expression of $H A C 1$ can give the highest activity of $20.7 \mathrm{U} / \mathrm{mL}$.

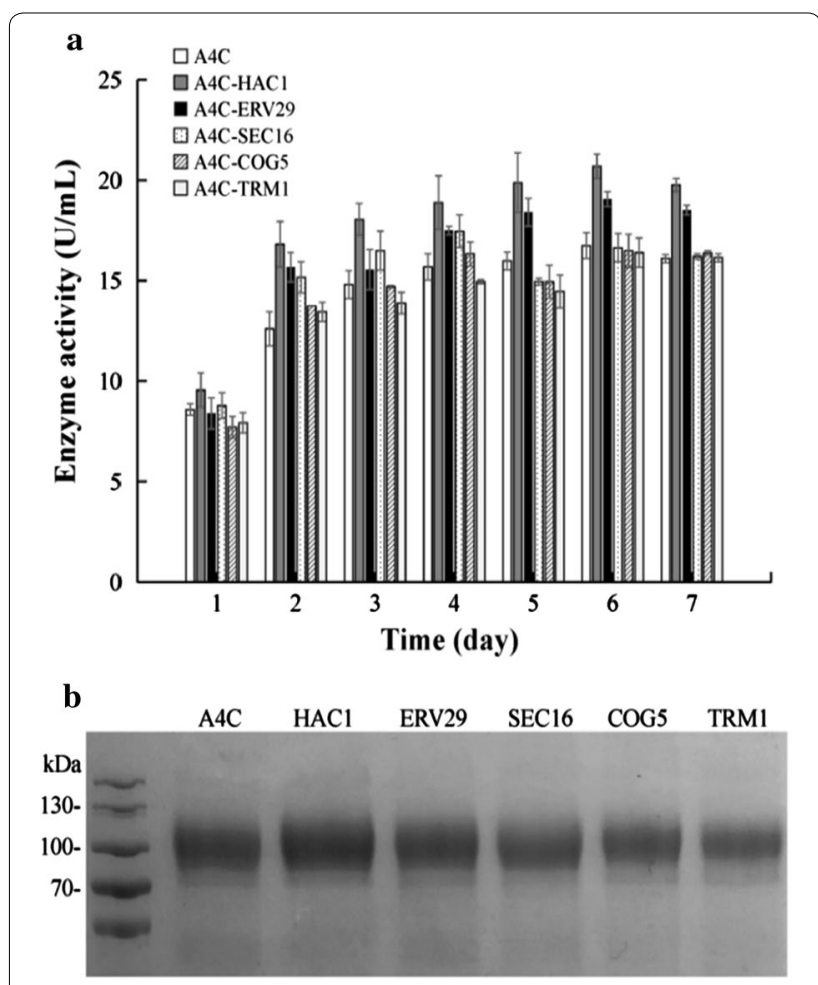

Fig. 2 Chitinase activities and SDS-PAGE analysis of fermentation supernatant of A4C with different chaperones. a Chitinase activities in the fermentation supernatant. $\mathbf{b}$ SDS-PAGE analysis of fermentation supernatant $(8 \mu \mathrm{L})$. lane 1: A4C, lanes $2-6$ : A4C co-expression of HAC1, SEC16, ERV29, COG5 and TRM1, respectively

\section{Expression of ChiA using high-cell-density fermentation} In order to further improve the expression level of ChiA, high-cell-density fermentation of A4C-HAC1 was

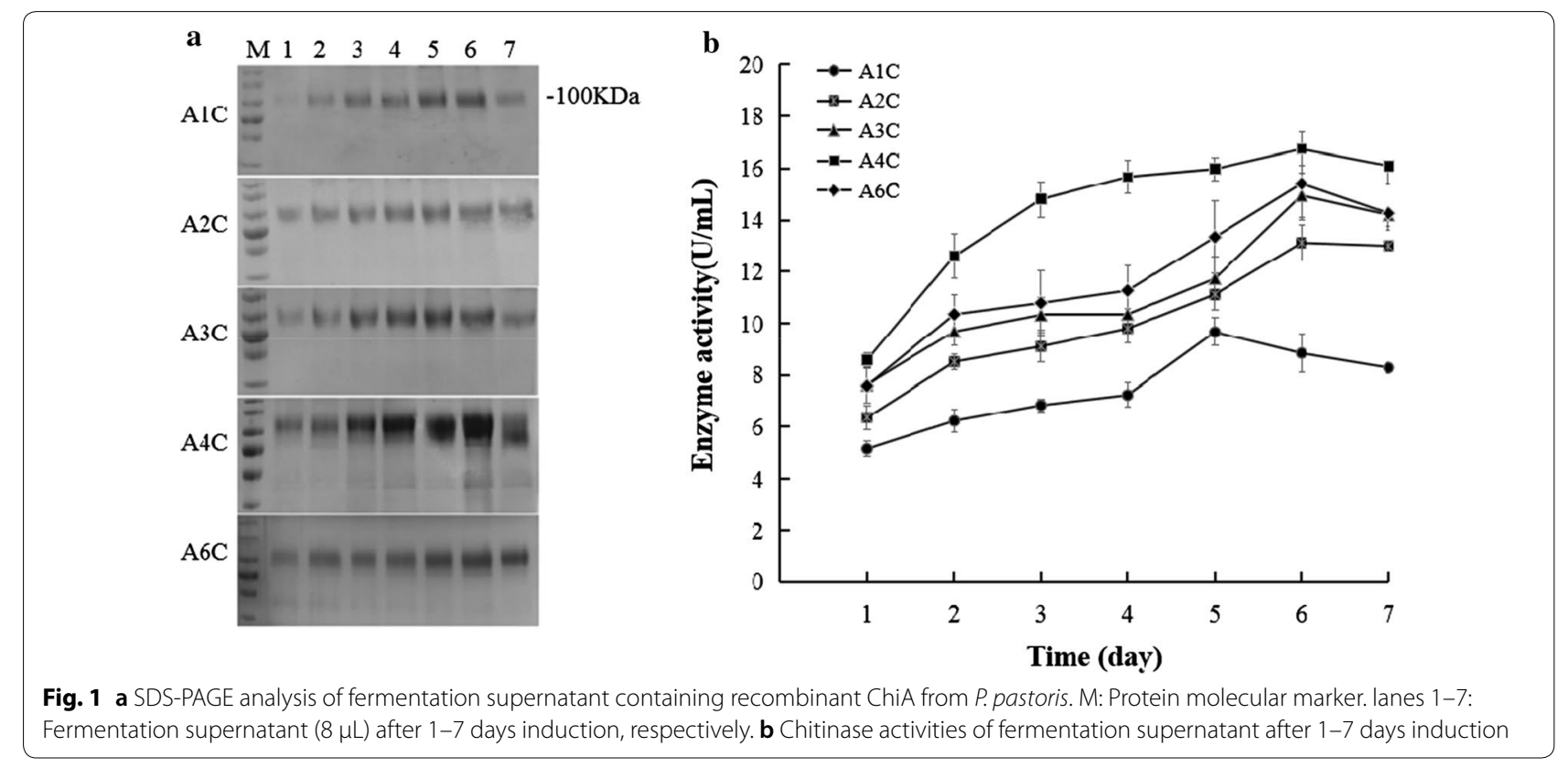


performed in a $5 \mathrm{~L}$ fermenter. The samples were collected every $12 \mathrm{~h}$, and the whole methanol induction time was $144 \mathrm{~h}$. The maximum enzyme activity in the supernatant reached $168.78 \mathrm{U} / \mathrm{mL}$ after $120 \mathrm{~h}$ induction, eightfold higher than in shake flask, and the amount of secreted ChiA kept increasing to reach a maximum of $12.70 \mathrm{mg} / \mathrm{mL}$ (Fig. 3a), which was ninefold higher than the shake flask fermentation $(1.40 \mathrm{mg} / \mathrm{mL})$. When the enzyme activity reached the highest, the final cell density of $\mathrm{OD}_{600}$ and wet weight reached 331 and $378 \mathrm{~g} / \mathrm{L}$, respectively.

\section{Recombinant ChiA hydrolyzing colloidal chitin at different concentrations}

Menghiu et al. determined the hydrolysis products of recombinant ChiA from $P$. pastoris by TLC using $2 \%$ colloidal chitin as substrate, which showed the reaction products were mainly $N, N^{\prime}$-diacetylchitobiose, followed by GlcNAc, and considered that ChiA is an endochitinase [10]. As we known, high substrate concentration can give more products in a limited reaction volume, however,

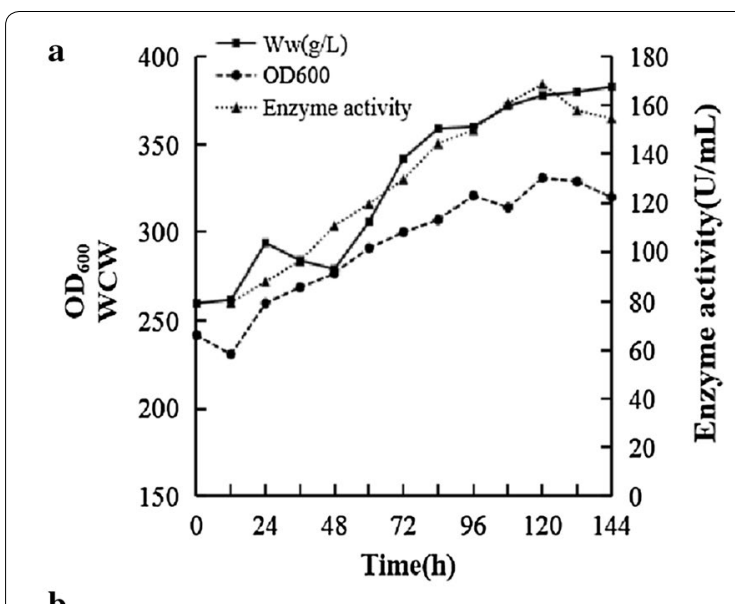

b

$\begin{array}{lllllllllllll}M & 1 & 2 & 3 & 4 & 5 & 6 & 7 & 8 & 9 & 10 & 11 & 12\end{array}$

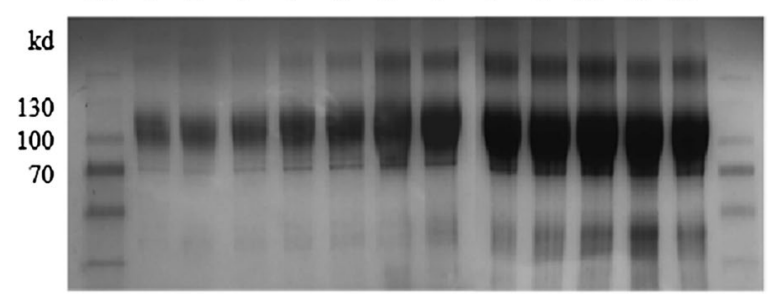

Fig. 3 The high-cell-density fermentation of the recombinant P. pastoris A4C co-expressing $\mathrm{HACl}$ in a $5 \mathrm{~L}$ fermenter. a The growth curve $\left(\mathrm{OD}_{600}\right)$, WCW and chitinase activity of fermentation supernatant with different induction time. $\mathbf{b}$ SDS-PAGE analysis of fermentation supernatant $(8 \mu \mathrm{L})$ with different induction time. lane $\mathrm{M}$, Prestained protein marker; lanes 1-12, The fermentation supernatants after being induced for $0,12,24,36,48,60,72,84,96,108,120$ and $132 \mathrm{~h}$, respectively high concentration products may inhibit the enzymatic reaction. Thus, in order to explore the optimal concentration of colloidal chitin hydrolyzed by recombinant ChiA, we tried to use excessive ChiA hydrolyze different concentration colloidal chitin. The results showed that the conversion ratio of $10 \%, 15 \%, 25 \%, 30 \%, 35 \%$ and $40 \%$ (w/v) colloidal chitin can reach $89 \%, 80 \%, 78 \%, 74 \%, 69 \%$ and $62 \%$, respectively. When hydrolyzed $30 \%(\mathrm{w} / \mathrm{v})$ colloidal chitin, the yield of products looks more higher than the others by HPLC analysis (Fig. 4a). When the substrate concentration was improved to $40 \%$, the yield didn't increase. Thus, $30 \%(\mathrm{w} / \mathrm{v})$ colloidal chitin was selected as the suitable substrate concentration. We also found that more GlcNAc are obtained in the hydrolysate, and $N, N^{\prime}$ diacetylchitobiose gradually decreased, which is different from the previous report that $N, N^{\prime}$-diacetylchitobiose as the most abundant hydrolysis product by the recombinant ChiA from P. pastoris [10], and consistent with the report that colloidal chitin was hydrolyzed by the recombinant ChiA from E. coli up to 3 days at $50{ }^{\circ} \mathrm{C}$, GlcNAc gradually increased [9]. These results implied that $N$, $N$-diacetylchitobiose can be hydrolyzed by ChiA to GlcNAc, while no previous reports investigated whether this enzyme can hydrolyze $N, N^{\prime}$-diacetylchitobiose. Thus, the $N, N^{\prime}$-diacetylchitobiose was used as a substrate to confirm whether the ChiA have the hydrolytic ability on it. We found $N, N^{\prime}$-diacetylchitobiose can be hydrolyzed by ChiA into GlcNAc weakly, the conversion ratio is $34 \%$ even the excessive ChiA was used (Fig. 4b).

ChiA/BsNagZ hydrolyzing colloidal chitin to obtain GIcNAc $\beta$ - $N$-acetylglucosaminidase BsNagZ has been identified to cut the colloidal chitin from the terminal to obtain GlcNAc at low efficiency [25]. Here, a mixture of $600 \mu \mathrm{L}$ of $30 \%$ (w/v) colloidal chitin and $200 \mu \mathrm{L}$ ChiA $(18 \mathrm{U} / \mathrm{mL})$ was incubated at $50{ }^{\circ} \mathrm{C}$ for $12 \mathrm{~h}$, and then $200 \mu \mathrm{L}$ BsNagZ $\left(5 \mathrm{U} / \mathrm{mL}\right.$ ) was added and the mixture was kept at $60{ }^{\circ} \mathrm{C}$ for another $20 \mathrm{~min}$. The results showed that GlcNAc is the only product, it can be produced efficiently when BsNagZ was used as a supplement (Fig. 4c), and the conversion ratio can reach $88 \%$.

\section{The effects of different hydrolysis products on the germination of rice and wheat seeds}

Different chitin-oligosaccharides have different optimal concentrations for different crops [26], in our experimental condition, we found ChiA 12 h-hydrolyzed products on colloidal chitin (a mixture of $N, N^{3}$-diacetylchitobiose and GlcNAc) with a concentration of $300 \mu \mathrm{g} / \mathrm{mL}$ (Table 2, Fig. 5a) had the best effect for rice germination, and $10 \mu \mathrm{g} / \mathrm{mL}$ for wheat (Table 2, Fig. $5 \mathrm{~b}$ ). When the concentration of chitin-oligosaccharides 


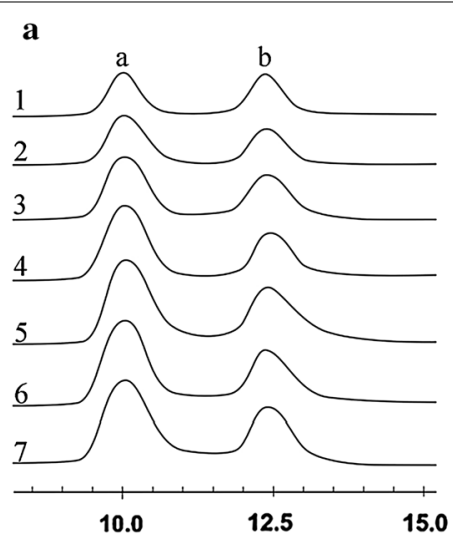

b
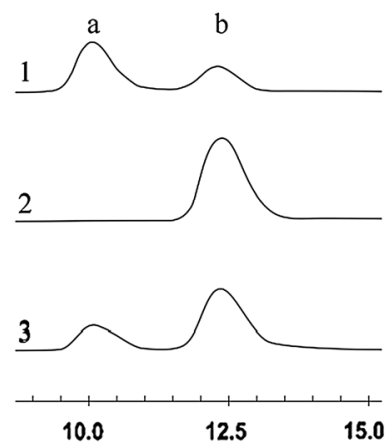

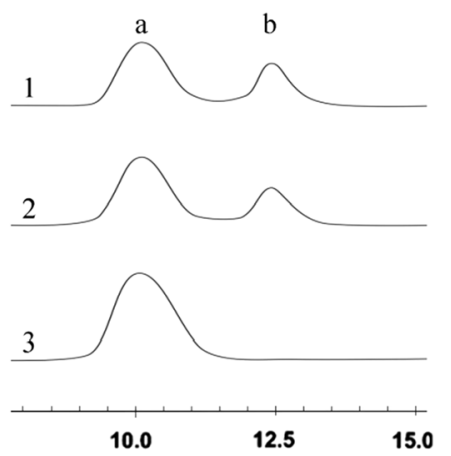

Fig. 4 Analysis of hydrolysis products by HPLC. a The hydrolysis products of colloidal chitin with different concentration by recombinant ChiA for 12 h. 1: Standard of GlcNAc (peak a) and N, N'-diacetylchitobiose (peak b). 2-7: 10\%, 15\%, 25\%, 30\%, 35\%, 40\% colloidal chitin as substrate, respectively. $\mathbf{b}$ The hydrolysis products of $N, N^{\prime}$-diacetylchitobiose by recombinant ChiA. 1: Standard of GlcNAc (peak a) and N, $N^{\prime}$-diacetylchitobiose (peak b). 2, 3: The hydrolysis product of $N$, $N^{\prime}$-diacetylchitobiose by recombinant ChiA at 0,20 min, respectively. C The hydrolysis products of colloidal chitin by recombinant ChiA/BsNagZ. 1: Standard of GlcNAc (peak a) and N, N'-diacetylchitobiose (peak b). 2, 3: The hydrolysis product of colloidal chitin by recombinant ChiA for $12 \mathrm{~h}$ and then with recombinant BsNagZ for 0 (2), 20 min (3)

Table 2 The effects of hydrolyzate by ChiA with different concentration on the germination of rice and wheats seeds

\begin{tabular}{|c|c|c|c|c|c|}
\hline Plant & Concentration $(\mu \mathrm{g} / \mathrm{ml})$ & Seeding length $(\mathrm{cm})$ & $\begin{array}{l}\text { Increasing percent } \\
\text { (\%) }\end{array}$ & Root length $(\mathrm{cm})$ & $\begin{array}{l}\text { Increasing } \\
\text { percent (\%) }\end{array}$ \\
\hline \multirow[t]{5}{*}{ Rice } & 0 & $3.5 \pm 0.5$ & - & $3.2 \pm 0.9$ & - \\
\hline & 50 & $4.9 \pm 0.9$ & 40 & $4.1 \pm 0.3$ & 28 \\
\hline & 150 & $6.0 \pm 0.7^{* *}$ & 71 & $6.1 \pm 1.6$ & 190 \\
\hline & 300 & $6.5 \pm 0.6^{* *}$ & 86 & $6.3 \pm 0.7^{*}$ & 197 \\
\hline & 500 & $5.8 \pm 0.5^{* *}$ & 66 & $3.8 \pm 0.9$ & 18 \\
\hline \multirow[t]{5}{*}{ Wheat } & 0 & $3.8 \pm 0.9$ & - & $3.2 \pm 0.6$ & - \\
\hline & 1 & $5 \pm 1.3$ & 32 & $4.8 \pm 1.1$ & 50 \\
\hline & 10 & $6.8 \pm 0.3^{* *}$ & 79 & $7 \pm 0.7^{* *}$ & 119 \\
\hline & 25 & $5.5 \pm 0.3$ & 45 & $5.8 \pm 0.3^{* *}$ & 81 \\
\hline & 100 & $3.3 \pm 1.2$ & -13 & $3.6 \pm 0.9$ & 12 \\
\hline
\end{tabular}

${ }^{*} \mathrm{P}<0.05$ (significant difference), ${ }^{* *} \mathrm{P}<0.01$ (Extremely significant difference)

increased further, the effects of growth promotion of rice and wheat became worse.

ChiA/BsNagZ hydrolyzed products on colloidal chitin (monosaccharide) were also diluted to the suitable concentration to evaluate the effects on seeds germination. The phosphate buffer was used as a control. The results showed that the hydrolysis product of ChiA can increase the seedling height and root length up to 1.7fold and 2.2-fold on rice (Fig. 5c), and up to 1.8-fold and 1.6-fold on wheat (Fig. 5d), respectively (Additional file 1: Table S1). The monosaccharide obtained from ChiA/ BsNagZ combined hydrolysis can increase the seedling height and root length of rice up to 1.5-fold and 1.9fold (Fig. 5c), and up to 1.3-fold and 1.5-fold for wheat (Fig. 5d), respectively (Fig. 6, Additional file 1: Table S1).

\section{Discussion}

In previous study, the chitinase A from B. licheniformis has been expressed in the $P$. pastoris firstly. The maximum yield of ChiA in the supernatant of flask is only $0.506 \mathrm{mg} / \mathrm{mL}$ [10]. In our study, the multi-copy strategy was used to improve the expression obviously. The strain with 4 copies of ChiA gene produced the highest enzyme activity of $16.74 \mathrm{U} / \mathrm{mL}(1.13 \mathrm{mg} / \mathrm{mL})$ in the supernatant of flask, compared with the 1, 2, 3 and 6 copies of ChiA gene. From our results, the copy number of the gene is not proportional to the amount of expressed protein (Additional file 1: Fig. S4). Similar results in different protein cases have been reported before. The recombinant lactone hydrolase ZHD from Gliocladium roseum has been expressed in P. pastoris. 

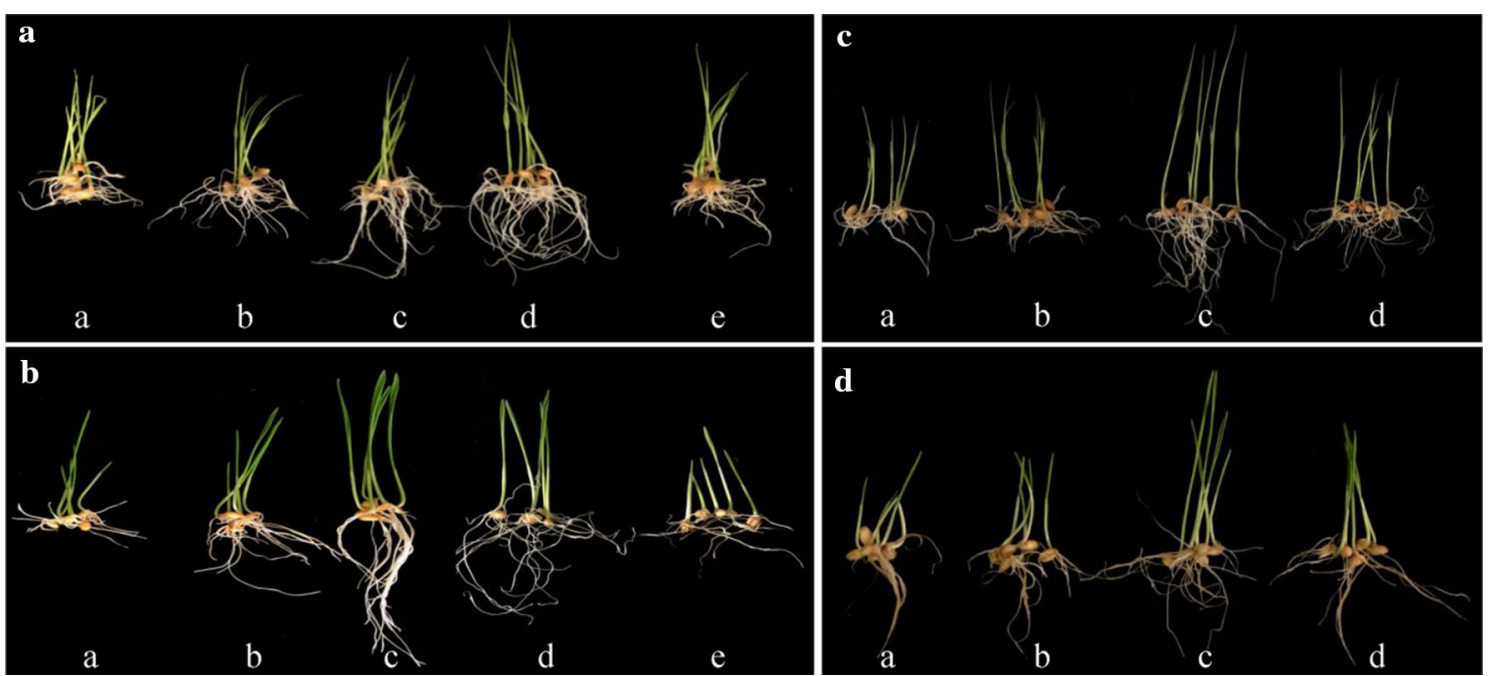

Fig. 5 Effects of the hydrolysis products on the germination growth of plants. a Different concentration hydrolysis products by ChiA on rice seeds germination. a-e water, $50 \mu \mathrm{g} / \mathrm{mL}, 150 \mu \mathrm{g} / \mathrm{mL}, 300 \mu \mathrm{g} / \mathrm{mL}$ and $500 \mu \mathrm{g} / \mathrm{mL}$. b Different concentration hydrolysis products by ChiA on wheat seeds germination. a-e: water, $1 \mu \mathrm{g} / \mathrm{mL}, 10 \mu \mathrm{g} / \mathrm{mL}, 25 \mu \mathrm{g} / \mathrm{mL}$ and $100 \mu \mathrm{g} / \mathrm{mL}$. c Effects of different hydrolysis products on rice seed germination. (a) water, (b) pH6 phosphate buffer, (c) $300 \mu \mathrm{g} / \mathrm{mL}$ ChiA hydrolyzed colloidal chitin product, (d) $300 \mu \mathrm{g} / \mathrm{mL}$ ChiA/BsNagZ hydrolyzed colloidal chitin product (monosaccharide). $\mathbf{d}$ Effects of different hydrolysis products on wheat seed germination. (a) water, (b) pH6 phosphate buffer, (c) $10 \mu \mathrm{g} / \mathrm{mL}$ ChiA hydrolyzed colloidal chitin product, (d) $10 \mu \mathrm{g} / \mathrm{mL}$ ChiA/BsNagZ hydrolyzed colloidal chitin product (monosaccharide)

The recombinant $P$. pastoris X3C contained 3 copies of $Z H D$ present higher expression than the one with the 4 copies [12]. When 1-4 copies of ophcM-expressing cassettes were transformed into P. pastoris, 2-copy tandem ophcM-expressing cassettes produced the maximum yield [13]. The reason may be that the high gene copy number will intense the cellular stress and reduce the extracellular secretion of the protein [27]. The copy

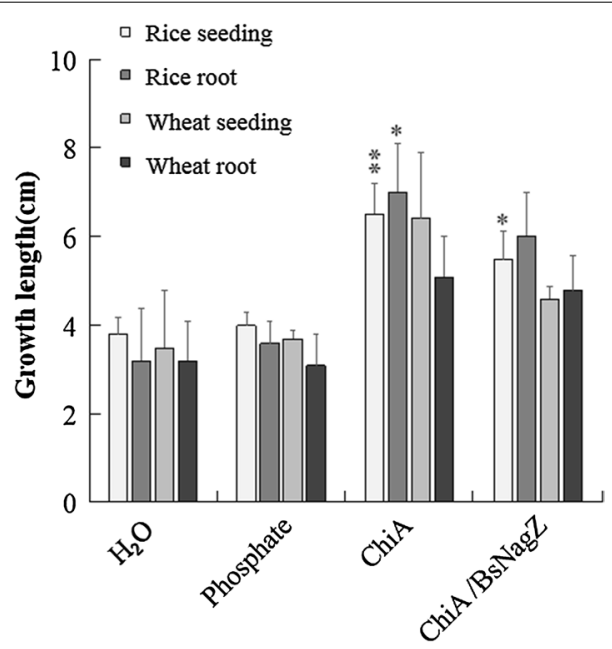

Fig. 6 The effects of different hydrolyzate on the germination of rice and wheats seeds. Bars indicated mean $\pm S D(n=3$ biological replicates); T-tests were noted as ${ }^{*} P<0.05$ or ${ }^{*} P<0.01$. ChiA and ChiA/BsNagZ means hydrolysis products by ChiA or ChiA/BsNagZ respectively number of gene is not directly proportional to the expression level of protein. Excessive gene copy number may decrease the protein expression level. There are three main speculations in the published papers, the first one is high gene copy number may lead to metabolic burden on the level of central carbon metabolism through metabolic flux analysis, thus limitation in the carbon and energy supply lower the protein level [28]. The second is transcriptome analysis showed that increased dosage of AOX1 promoter-regulated expression cassettes leads to transcription attenuation of the methanol utilization genes, and subsequent experiment also found reduced methanol consumption rates, which may decrease the translation of target protein [29]. The third is mass expressed heterologous protein may cause stress on the secretory pathway, leading to the upregulation of the unfolded protein response (UPR) and resulting in degradation of the protein, which will cause secretion saturation [27]. Since HAC1 can trigger the unfolded protein response (UPR), co-expression of $\mathrm{HAC} 1$ can improve the secretion of target protein in our and many other studies [27, 30], which also support this speculation. Actually, there is no definite evidence to explain how the gene copy number affect the corresponding expression level, it is a long way to go.

Molecular chaperones were reported to be an effective method to improve the expression of heterologous protein since they can facilitate unfolded or partially folded protein to be correct folding, finally improve the 
properties of protein. Here five molecular chaperones HAC1, EVR29, SEC16, COG5 and TRM1 have been coexpressed separately with 4 copies of ChiA in P. pastoris. It is the first time to try co-expression of TRM1, EVR29 and COG5 with heterologous protein in P. pastoris. Coexpressing ChiA with SEC16, COG5 and TRM1 separately did not improve the ChiA expression significantly. Here co-expression of $H A C 1$ and ERV29 separately increased the ChiA yield from 16.74 to $20.69 \mathrm{U} / \mathrm{mL}$ and $19.00 \mathrm{U} /$ $\mathrm{mL}$ in the fermentation supernatant of flask. Huang et al. reported that overexpressed $E R V 29$ or COG5 individually could improved the secretion level of amylase in S. cerevisiae. It is likely that the improved activity of amylase in the ERV29 overexpressed strain was related to enhancement of the ERV29p-dependent transport. When the COG5 were overexpressed, the retrograde vesicles trafficking strengthened, which was beneficial for amylase production [31]. However, the co-expression of SEC16 and COG5 promotes the secretion of heterologous proteins for the first two days in this study, then has little effect afterwards. We speculate that the reason may be caused by the shorter period of induced protein expression in $S$. cerevisiae, while $P$. pastoris requires longer induction time. Strangely, overexpression of $H A C 1$ and $E R V 29$ simultaneously did not further increase expression compared with that of single chaperone expression, which may due to its redundant function.

Meanwhile, our study used high-cell-density fermentation to express the recombinant ChiA for the first time. In our work, the maximum expression level in the supernatant of high-cell-density fermentation reached $12.70 \mathrm{mg} / \mathrm{mL}$ after $120 \mathrm{~h}$ methanol induction and the activity toward colloidal chitin was $168.78 \mathrm{U} / \mathrm{mL}$, which was tenfold higher than that of shake flask fermentation. In the previous report, the expression of ChiA in P. pastoris is $0.506 \mathrm{mg} / \mathrm{mL}$ in the $1 \mathrm{~L}$ flask supernatant and the activity toward colloidal chitin was $1.70 \mathrm{U} / \mathrm{mL}$. When expressed in $P$. pastoris, the activity was measured using $84 \mathrm{mg} / \mathrm{mL}(8.4 \%)$ colloidal chitin, incubated at $37^{\circ} \mathrm{C}$ for $2 \mathrm{~h}$ [10]. In our study, we used $2 \%$ colloidal chitin at $50^{\circ} \mathrm{C}$ for $10 \mathrm{~min}$. In our knowledge, chitin purchased from different companies have a great impact on the measurement of enzyme activity, so we cannot compare the enzyme activity accurately. However, the protein concentration of chitinase $(12.70 \mathrm{mg} / \mathrm{mL})$ was about 24 -fold higher than the previous report $(0.506 \mathrm{mg} / \mathrm{mL})$ [10] Thus, combining with the multi-gene copy tandem and molecular chaperone co-expression, the high-cell-density fermentation demonstrated to be an efficient strategy to increase the yield of recombinant chitinase in P. pastoris.

Usually, high concentration of substrate would inhibit the enzyme activity, while in industry application, high concentration of substrate can reduce the reaction volume to lower the production cost. In our experimental conditions, the optimal colloidal chitin substrate concentration was $30 \%(\mathrm{w} / \mathrm{v})$, which was higher than the $84 \mathrm{mg} /$ $\mathrm{mL}(8.4 \%)$ reported before [10], and the conversion ratio was better. When the substrate concentration was more than $30 \%$, the conversion rate no longer significantly increased. To our knowledge, this is the first report that a $74 \%$ conversion ratio was achieved even with a high concentration of colloidal chitin at $30 \%$.

Some chitinanses can be potentially applied in the enzymatic preparation of GlcNAc. Sashiwa et al. reported that GlcNAc can be produced from $\alpha$-chitins with $64-77 \%$ yields up to 10 days using $A$. hydrophila $\mathrm{H}-2330$ crude enzyme extracts [32]. Cardozo et al. used the enzyme extracts from marine-derived Aeromonas to produce GlcNAc from colloidal $\alpha$-chitin, the highest GlcNAc yield was $93 \%$ after $24 \mathrm{~h}$ hydrolysis [33]. All these researches used the crude enzyme to obtain GlcNAc. Shun Jiang et al. reported that commercial chitinase CtnSg can hydrolyze $3 \%$ colloidal chitin into $N, N^{p}$-diacetylchitobiose, and then hydrolyze into GlcNAc by a heterologous expressed $\beta$ - $N$-acetylglucosaminidase BsNagZ [25]. In our case, when combined with BsNagZ, ChiA could hydrolyze $30 \%$ colloidal chitin to the unique product GlcNAc. The activity of ChiA is much higher than the commercial chitinase CtnSg, the cost will decrease significantly for the industrial application to produce GlcNAc. Thus, the enzyme-coupled system of ChiA would provide the new choice to get more GlcNAc for industrial demand.

It was reported that oligosaccharides, especially chitin-oligosaccharides, can promote the growth of some plant species [34, 35]. In our seed germination experiment, we found that the hydrolysis product of ChiA can increase $71 \%$ seedling height and $119 \%$ root length of rice, increase $83 \%$ seedling height and $59 \%$ root length of wheat respectively. The monosaccharide obtained from ChiA/BsNagZ hydrolyze colloid chitin can increase $45 \%$ seedling height and $87 \%$ root length of rice, increase $31 \%$ seedling height and 50\% root length of wheat respectively. Yunhong et al. showed $0.05 \%$ chitin oligosaccharides (Degree of polymerization 2-8) could promote the formation of shoot-borne roots of wheat, but there is no obvious growth-promoting effect on wheat seedlings [36]. Jianxin et al. used the chitinase from Arthrobactor sp. to hydrolyze $1 \%$ colloidal chitin, the hydrolysate (Degree of polymerization 2-6) with low concentration can increase $39 \%$ seedling height of rice while the root growth was slightly inhibited. Otherwise, the growth of rice roots and seedlings were inhibited by the hydrolysate with high concentration [37]. Hongjuan et al. reported $1 \mu \mathrm{g} /$ $\mathrm{mL}$ chitosan (MW $2 \mathrm{kD}$ ) can significantly increase the growth of wheat root and seedling to $19.2 \%$ and $23.1 \%$, 
while $10 \mu \mathrm{g} / \mathrm{mL}$ chitosan inhibit their growth [38]. In all, different composition and content of oligosaccharides have different effects on plant growth [26]. The hydrolysis products used in our experiment only contains GlcNAc and $N, N^{\prime}$-diacetylchitobiose, with low degree of polymerization, has a better effect on promoting plant germination growth than many other reports, which is of great significance for increasing crop yields and increasing income.

\section{Conclusion}

Here, the ChiA gene from B. licheniformis has been highly expressed in P. pastoris. The activity of ChiA in the fermentation supernatant reached $168.78 \mathrm{U} / \mathrm{mL}$ with $12.7 \mathrm{mg} / \mathrm{mL}$ protein, which is the highest data reported until now. The recombinant ChiA can hydrolyze $30 \%$ collodidal chitin into GlcNAc and $N, N^{\prime}$-diacetylchitobiose with high conversion ratio. Combined with BsNagZ, GlcNAc can be obtained as the only product. Additionally, the hydrolysate of ChiA alone or combining with BsNagZ can obviously accelerate the germination growth of rice and wheat.

\section{Supplementary information}

Supplementary information accompanies this paper at https://doi. org/10.1186/s12934-020-01440-y.

Additional file 1: Table S1. The effects of different hydrolyzate on the germination of rice and wheat seeds. Fig. S1. Construction of pHBM905M-ChiA recombinant plasmids. AOX1: d1 + 2 × 201 AOX 1 promoter; a-factor: MF4I-SS signal peptide; TT: AOX1 terminator. Fig. S2. Construction of multi-copy the target gene expression cassettes based on the pHBM905BDM vector. (A) Schematic diagram of constructing recombinant plasmids containing two copy ChiA expression cassettes. (B) Sall digestion of multi-copy expression plasmids. lane M: $\lambda$-EcoT14 digestion marker; lane 1-5: The plasmids pHBM905M-ChiA-1 copy, -2copy, -3copy, -4 copy, and -6copy by Sall digestion, respectively. Fig. S3. Construction of pGAPZB-HAC1/ERV29/SEC16/COG5/TRM1 recombinant plasmids. PGAP: GAP promoter; AOX1 TT: AOX1 terminator; PTEF1:TEF1 promoter; PEM7: EM7 promoter; CYC1TT: CYC1 terminator. Fig. S4. Relationship between copy number and enzyme activity. The data used is the highest enzyme activity in per copy number.

\section{Acknowledgements}

The authors would like to thank Shouwen Chen (Hubei University, China) for kind donation of B. licheniformis WX-02.

\section{Authors' contributions}

WS, NZ and MY performed the experiments. NH contributed the conceptualization and helped the data analysis. GZ conceived the idea for the project, analyzed the results and wrote the paper with WS and NH. All authors read and approved the final manuscript.

\section{Funding}

This study was supported by National Key R\&D Program of China (NO.2018YFA0901102), Natural Science Foundation of Hubei Province (2018CFA042) and 2016 Wuhan Yellow Crane Talents (Science) Program.

\section{Availability of data and materials}

The data collected upon which this article is based upon are all included in this manuscript.
Ethics approval and consent to participate Not applicable.

\section{Consent for publication}

Not applicable.

\section{Competing interests}

The authors declare the following competing financial interests: The authors have a filed patent application related to this paper.

Received: 25 August 2020 Accepted: 10 September 2020

Published online: 15 September 2020

\section{References}

1. Hamed I, Özogul F, Regenstein JM. Industrial applications of crustacean by-products (chitin, chitosan, and chitooligosaccharides): a review. Trends Food Sci Technol. 2016:48:40-50.

2. Fu X, Yan $Q$, Yang $S$, Yang $X$, Guo Y, Jiang Z. An acidic, thermostable exochitinase with $\beta$ - $N$-acetylglucosaminidase activity from Paenibacillus barengoltzii converting chitin to $\mathrm{N}$-acetyl glucosamine. Biotechnol Biofuels. 2014;7:174.

3. Ma Z, Yang L, Yan H, Kennedy JF, Meng X. Chitosan and oligochitosan enhance the resistance of peach fruit to brown rot. Carbohyd Polym. 2013;94:272-7.

4. Yin H, Du Y, Dong Z. Chitin oligosaccharide and chitosan oligosaccharide: two similar but different plant elicitors. Front Plant Sci. 2016;7:522.

5. Kariya Y, Kawamura C, Tabei T, Gu J. Bisecting GlcNAc residues on laminin-332 down-regulate galectin-3-dependent keratinocyte motility. J Biol Chem. 2010;285:3330-40.

6. Zhang J, Kopparapu NK, Yan Q, Yang S, Jiang Z. Purification and characterisation of a novel chitinase from persimmon (Diospyros kaki) with antifungal activity. Food Chem. 2013;138:1225-32.

7. Li L, Li K, Wang K, Chen C, Gao C, Ma C, Xu P. Efficient production of 2, 3-butanediol from corn stover hydrolysate by using a thermophilic Bacillus licheniformis strain. Biores Technol. 2014;170:256-61.

8. Lu L, Wang T-N, Xu T-F, Wang J-Y, Wang C-L, Zhao M. Cloning and expression of thermo-alkali-stable laccase of Bacillus licheniformis in Pichia pastoris and its characterization. Biores Technol. 2013;134:81-6.

9. Songsiriritthigul C, Lapboonrueng S, Pechsrichuang P, Pesatcha P, Yamabhai M. Expression and characterization of Bacillus licheniformis chitinase (ChiA), suitable for bioconversion of chitin waste. Biores Technol. 2010;101:4096-103.

10. Menghiu G, Ostafe V, Prodanovic R, Fischer R, Ostafe R. Biochemical characterization of chitinase A from Bacillus licheniformis DSM8785 expressed in Pichia pastoris KM71H. Protein Expr Purif. 2019;154:25-32.

11. Li Y, Yi P, Liu J. High-level expression of an engineered $\beta$-mannanase (mRmMan5A) in Pichia pastoris for manno-oligosaccharide production using steam explosion pretreated palm kernel cake. Biores Technol. 2018;256:30-7.

12. Xiang $L$, Wang $Q$, Zhou Y, Yin L, Zhang G, Ma Y. High-level expression of a ZEN-detoxifying gene by codon optimization and biobrick in Pichia pastoris. Microbiol Res. 2016;193:48-56.

13. Shen W, Shu M, Ma L, Ni H, Yan H. High level expression of organophosphorus hydrolase in Pichia pastoris by multicopy ophcM assembly. Protein Expr Purif. 2016;119:110-6.

14. Hu Y, Zhang G, Li A, Chen J, Ma L. Cloning and enzymatic characterization of a xylanase gene from a soil-derived metagenomic library with an efficient approach. Appl Microbiol Biotechnol. 2008;80:823-30.

15. Yu X, Zhai C, Zhong X, Tang W, Wang X, Yang H, Chen W, Ma L. High-level expression and characterization of carboxypeptidase $Y$ from Saccharomyces cerevisiae in Pichia pastoris GS115. Biotech Lett. 2015;37:161-7.

16. He H, Zhai C, Mei M, Rao Y, Liu Y, Wang F, Ma L, Jiang Z, Zhang G, Yi $L$. Functional expression of porcine interferon-a using a combinational strategy in Pichia pastoris GS115. Enzyme Microbial Technol. 2019;122:55-63.

17. Zirpel B, Degenhardt F, Zammarelli C, Wibberg D, Kayser O. Optimization of $\Delta 9$-tetrahydrocannabinolic acid synthase production in Komagataella phaffii via post-translational bottleneck identification. J Biotechnol. 2018;272-273:40. 
18. Sahu U, Rao KK, Rangarajan PN. Trm1p, a Zn (II) 2Cys6-type transcription factor, is essential for the transcriptional activation of genes of methano utilization pathway, in Pichia pastoris. Biochem Biophys Res Commun. 2014;451:158-64.

19. Bao J, Huang M, Petranovic D, Nielsen J. Moderate expression of SEC16 increases protein secretion by Saccharomyces cerevisiae. Appl Environ Microbiol. 2017;83:03400-16.

20. Ying Y, Garcia MR, Novak AJ, Saunders AM, Ank RS, Nam AS, Fisher LW. Surf4 (Erv29p) binds amino-terminal tripeptide motifs of soluble cargo proteins with different affinities, enabling prioritization of their exit from the endoplasmic reticulum. PLoS Biol. 2018;16:e2005140.

21. Shindel A. Erectile dysfunction predicts cardiovascular events in high-risk patients receiving telmisartan, ramipril, or both: the ONgoing telmisartan alone and in combination with ramipril global endpoint trial/ telmisartan randomized AssessmeNt Study in ACE iNtolera. Circulation. 2010;121:1439-46.

22. Miller GL. Use of dinitrosalicylic acid reagent for determination of reducing sugar. Anal Biochem. 1959;31:426-8.

23. Jeen-Kuan Chen, Chia-Rui Shen, Chao-Hsien Yeh, Bing-Shiun Fang, TungLi Huang. N-Acetyl glucosamine obtained from chitin by chitin degrading factors in chitinbacter tainanesis. Int J Mol Sci. 2011;12:1187-95.

24. Resina D, Cos O, Ferrer P, Valero F. Developing high cell density fed-batch cultivation strategies for heterologous protein production in Pichia pastoris using the nitrogen source-regulated FLD1 Promoter. Biotechnol Bioeng. 2005;91:760-7.

25. Jiang $S$, Jiang H, Zhou Y, Jiang S, Zhang G. High-level expression of $\beta-N$-Acetylglucosaminidase BsNagZ in Pichia pastoris to obtain GlcNAc. Bioproc Biosyst Eng. 2019;42:611-9.

26. Hu X, Qiujin X, Xiangcan J, Jinghui L, Lijun L, Junxiu G, Kun O. Influence of the different concentration of chitosan oligosaccharide on ryegrass seeds germination and the disease-resistant enzyme activity of the seedling. Chin Agric Sci Bull. 2007;23:221-5.

27. Aw R, Polizzi KM. Can too many copies spoil the broth? Microb Cell Fact. 2013;12:128.

28. Jordà Joel, Jouhten P, Cámara E. |Metabolic flux profiling of recombinant protein secreting Pichia pastoris growing on glucose:methanol mixtures. Microb Cell Fact. 2012;11:57.

29. Cámara Elena, Landes Nils, Albiol Joan, Gasser Brigitte, Mattanovich Diethard. Ferrer P: increased dosage of AOX1 promoter-regulated expression cassettes leads to transcription attenuation of the methanol metabolism in Pichia pastoris. Scientific Reports. 2017;15:44302.
30. Huang M, Gao Y, Zhou X, Zhang Y, Cai M. Regulating unfolded protein response activator $\mathrm{HAC} 1 \mathrm{p}$ for production of thermostable rawstarch hydrolyzing a-amylase in Pichia pastoris. Bioproc Biosyst Eng. 2016;40:1-10.

31. Huang M, Wang G, Qin J, Petranovic D, Nielsen J. Engineering the protein secretory pathway of Saccharomyces cerevisiae enables improved protein production. Proc Natl Acad Sci. 2018;115:E11025-32.

32. Sashiwa H, Kawasaki N, Nakayama A, Muraki E, Aiba SI. Chemical modification of chitosan 14: 1 synthesis of water-soluble chitosan derivatives by simple acetylation. Biomacromolecules. 2002;3:1126-8.

33. Cardozo FA, Gonzalez JM, Feitosa VA, Pessoa A, Rivera ING. Bioconversion of a-chitin into $\mathrm{N}$-acetyl-glucosamine using chitinases produced by marine-derived Aeromonas caviae isolates. World J Microbiol Biotechnol. 2017;33:201.

34. Chatelain PG, Pintado ME, Vasconcelos MW. Evaluation of chitooligosaccharide application on mineral accumulation and plant growth in Phaseolus vulgaris. Plant Sci. 2014;215:134-40.

35. Suzuki T, Tomita-Yokotani K, Tsubura H, Yoshida S, Kusakabe I, Yamada K, Miki Y, Hasegawa K. Plant growth-promoting oligosaccharides produced from tomato waste. Biores Technol. 2002;81:91-6.

36. Zhang Y, Zhao X, Yin H, He A, Sun K. Effects of seed soaking with oligosaccharides on seed germination and seedling growth of wheat (Triticum aestivum L.). J Henan Agric Sci. 2014;43:16-21.

37. Wang J, Binyu L, Qiupin D. Study on properties of chitooligosaccharides from Arthrobacter sp. XW-02. J Anhui Agric Sci. 2010;38:3874-6.

38. Jing HJ, Wang SL, Tian HY, Wang LF, Guo XD, Industry H. University: effects of Chitosan on Early Growth and Physiology of Wheat Seedlings. J Triticeae Crops. 2013;33:1039-42.

\section{Publisher's Note}

Springer Nature remains neutral with regard to jurisdictional claims in published maps and institutional affiliations.
Ready to submit your research? Choose BMC and benefit from:

- fast, convenient online submission

- thorough peer review by experienced researchers in your field

- rapid publication on acceptance

- support for research data, including large and complex data types

- gold Open Access which fosters wider collaboration and increased citations

- maximum visibility for your research: over 100M website views per year

At BMC, research is always in progress.

Learn more biomedcentral.com/submissions 